\title{
Lacancı Söylem Kuramı: Histeriğin Söylemine dair bir Vaka Örneği
}

\author{
Elif Ünal* \\ Orta Doğu Teknik Üniversitesi
}

\section{$\ddot{O} z$}

Jacques Lacan, dilin özneler arası ilişkilerdeki rolünü ve bu ilişkilerdeki sosyal bağların niteliğini incelemek için söylem kuramını geliştirmiştir. Bu kuramda; efendi, üniversite, histerik ve analistin söylemi olmak üzere dört farklı söylem önerilmiştir. Her bir söylem dört psikolojik faktör ve pozisyon etrafında yapılanmaktadır. Söylemlerin konuşmada kullanılan kelimelerden önce geldiği ve hatta onları belirlediği vurgulanmaktadır. Lacan, bu dört söylemden biri olan histeriğin söyleminin konuşan her insanın ve dolayısıyla analizdeki kişinin de söylemi olduğunu öne sürmüştür. Bu söylem öznenin ötekinden cevaplar talep etmesi; ama bu cevaplar bilinçdışını yansıtamayacağı için asla tatmin olmaması ile karakterize olmaktadır. Lacan, öznenin bilinçdışına ulaşmanın bir yolu olarak analistin söylemini öne sürmüştür. Bu makalede, öncelikle söylemler kuramına dair kavramlar incelenmiş, sonrasında histeriğin söylemi bir vaka örneği çerçevesinde tartışılmış ve analistin söylemi kısaca açıklanmıştır.

Anahtar kelimeler: Lacan, söylemler, söylem kuramı, histeriğin söylemi, analistin söylemi 


\title{
Lacan's Theory of Discourses: A case example for the Hysterical Discourse
}

\author{
Elif Ünal* \\ Middle East Technical University
}

\begin{abstract}
Jacques Lacan developed the theory of discourses in order to understand the role of language and the social bonds among intersubjective relationships. Four different discourses were proposed as master, university, hysteric, and analytic discourse. Each discourse is structured around four psychological factors and four positions. It was empathized that the discourses even come before the spoken words and determine them. Lacan suggested that the hysterical discourse among the four discourses as the discourse of every speaking human being and so of the client in the therapy. It is characterized by demand to get answers from the other but never being satisfied because the answers of the questions could not match the unconscious desire. Lacan suggested analyst's discourse as the way of reaching the unconscious of the subject. In the current article; firstly, the concepts of the theory of discourses were examined, then hysterical discourse was discussed in the context of a case example, and analyst's discourse was brieflyexplained.
\end{abstract}

Keywords: Lacan, discourses, theory of discourses, hysterical discourse, analyst's discourse 


\section{Lacancı Söylem Kuramı: Histeriğin Söylemine dair bir Vaka Örneği}

Jacques Lacan çağdaş psikanalistlerin en tartışma yaratanlarından ve Freud'dan sonra bu disiplini en çok etkileyen kişilerinden biridir. Lacan Psikanalizin Diğer Taraf seminerinde (17. Seminer) "dilin kullanımının toplumsal yapıyı yöneten asıl olgu” olduğunu söylemiş ve dilin insan ilişkilerinde biçimlendirici ve dönüştürücü gücü olduğuna vurgu yapmıştır (Miller, 1991/2001, s.15). Lacan aynı zamanda dil ve arzu arasındaki ilişkinin anlaşılmasının psikanalitik süreçte temel amaç ve araç olduğunu öne sürmüş (Clemens \& Grigg, 2006), konuşmanın analizdeki önemine dikkat çekmiştir (Miller, 1991/2001). Bununla paralel, 17. Seminerini verdiği 1969-1970 yılları sırasında temel insan ilişkilerinde dilin rolünü analiz etmeye odaklanmış, konuşma eylemi yoluyla işleyen ve ilişkilerdeki sosyal bağın niteliğini belirlediğini düşündüğü söylem kuramını geliştirmiştir. Lacan'ın söylem kuramı esas olarak insan ilişkilerindeki sosyal bağları anlamak için önemli bir yol göstericidir (Marshall, 1994). Lacan söylemlerin konuşulan kelimelerden ve cümlelerden bağımsız olduğuna vurgu yapmış ve hatta söylemlerin konuşma sırasında kişilerin kullandıkları sözcükleri, duygu, düşünce ve davranışlarını belirlediğini öne sürmüştür (Verhaeghe, 1995).

\section{Lacancı Söylem Kuramı, Dört Pozisyon ve Psikolojik Faktör}

Lacan, söylem kuramında efendi, üniversite, histerik ve analistin söylemi olmak üzere dört söylem, yani olası dört toplumsal bağ tipi ya da özneler arası ilişkileri yönlendiren dört olası yapı formüle etmiştir. Söylemlerin her biri dört temel psikolojik faktör arasındaki farklı ilişkilerin birer sonucu olarak oluşmaktadır. Bu psikolojik faktörleri Lacan, "temel gösteren, bölünmüş nesne, bilgi ve küçük a nesnesi” olarak sıralamıştır. Söylem içinde her bir psikolojik faktörün özneler arası ilişkilerde olası dört temel konumda; fail, öteki, üretim ve hakikat, yer aldığını öne sürmüştür (Schroeder, 2008). Lacan diğer bulgularını ifade etmek için matematiksel formüllerden faydalandığı gibi söylem kuramında da özneler arası iletişimdeki olası dört konumun matrisini oluşturmuştur (Bkz. Şekil 1).

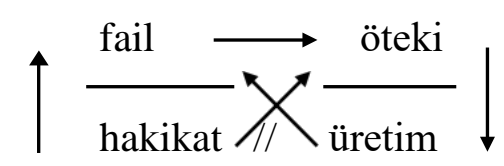

Şekil 1. Söylem Kuramı'nın dört pozisyona göre yapılanması.

İlk pozisyon söylem içinde mesajı gönderen, konuşan fail'in konumudur. Fail her hangi bir kişi olabileceği gibi bir kurum ya da yapı da olabilir. Bu pozisyon söylemde en etkin, belirgin ve baskın faktörün konumudur. Fail bir kişi, kurum ya da toplumsal yapı olabilecek öteki'ne konuşur, ona mesaj yollar ya da ona eyleme geçmesi için çağrıda bulunur. Dinleyen ötekinin varlığı ve harekete geçmesi söylemin işlemesi için ön koşuldur. Fail ve öteki arasındaki bu mesajı gönderen ve mesajı alan ilişkisi, failden ötekine hareket eden bir ok ile temsil edilir. Konuşan ve mesajın gönderildiği yer ya da fail ve öteki arasındaki bu ilişkinin sonucu olarak bir üretim olur. Bu sağ alt pozisyon aynı zaman da söylem sonucunda ortaya çıkan bir kaybl, atı̆̆ $l$ da temsil edebilir. Fail ve 
ötekinin ilişkisinin sonucu ötekinden üretime hareket eden bir ok ile temsil edilir. Bu dörtlü matristeki son pozisyon, aynı zamanda söylem kuramında psikanalitik bakış açısının yer bulduğu konum hakikat'tin pozisyonudur. Freud'un da öne sürdüğü gibi her insan konuşurken ya da bir eylem içindeyken bilinmeyen, bilinçdışı bir faktör ya da gerçekten yola çıkarak güdülenmektedir. Lacan açısından da konuşan özne onu konuşturan kendi bilinçdışı arzusunun farkında değildir. Bilinçdışı bu gerçeğin bilinmez, saklı olması ve failin bu gerçeğe direk ulamışımın, ona dair farkındalığının, o onu direk iletmesinin mümkün olmayışı fail ve gerçek arasına çizilmiş bir çizgi ile temsil edilir. Ayrıca, bu gizli gerçek failin konuşmasının altında yatan ve ona yön veren faktördür. Dolayısıyla her söylemin başlangıç noktası hakikatin konumudur. Bu ilişki, matriste hakikatten faile hareket eden bir okla temsil edilir. Matris içindeki çapraz oklar ise söylem içindeki dolaşımı temsil eder niteliktedir (Bracher, 1994; Fink, 1996; Schroeder, 2008).

Bu dört pozisyona ek olarak, söylemler kuramında iletişim sırasında oluşabilecek kesintileri ve hataları temsil eden iki kopukluk tanımlanır. Bu kavramlar kuramın önemli parçalarıdır. Daha önce de belirtildiği gibi, failin atta yatan gerçeği kavraması, dolayısıyla da arzunun tam olarak dile dökülmesi imkânsızdır. Sonuç olarak, her iletişimde ifade edilen, söze dökülen ya da ötekine iletilen mesaj ile gerçek arasında bir kopukluk söz konusu olacaktır. Bu durum Lacancı söylem kuramında matrisin üst kısmında yer alan imkânsızlık ile temsil edilir. Gerçeğin fail tarafindan ötekine tamamen iletilmesi mümkün olmadığından, bu ikisi arasındaki ilişkinin sonucu olarak üretilenin de söylemin başlangıç noktasında olan gerçeğe denk ve onu tam karşılıyor olması mümkün değildir. Dolayısıyla söylem baştaki bilinçdışı arzuyu tam olarak karşılayacak bir sonuç elde edilmesinde her zaman yetersiz kalacaktır. Bu durum söylem matrisinin alt kısmında yetersizlik olarak konumlandırılmıştır (Bkz. Şekil 2). Bu kopukluklardan dolayı gerçek ve ürün arasında bir nevi onları bağlayan bir ok yoktur. Bu kopuklukların ve aksaklıkların en önemli sonucu arzu tatmininin imkânsızlığıdır ki bu özneler arası bağın temelini oluşturur ve tüm söylemleri karakterize eder (Verhaeghe, 1995).

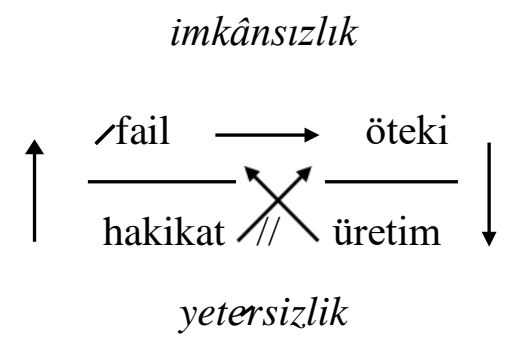

Şekil 2. Söylem matrisinde kopuklukların gösterimi.

Bu dört pozisyon birbirlerine ilişkileri bakımından matristeki yerlerinde sabit kalırken, her bir psikolojik işlevin hangi pozisyonda yer alacağı her söylem için farklıdır. Pozisyonlardaki bu farklılık her bir söylemin psikolojik faktörler açısından farklı yapılanmasını ortaya koyar (Schroeder, 2008). Şöyle ki pozisyonuna göre hangi söylemde hangi psikolojik faktörün ön planda olduğu, diğerini hareket geçirdiği, bastırıldığı ve sonuç olarak ortaya çıktığı görülebilmekte ve anlamlandırılabilmektedir. Lacan psikolojik faktörleri temsil eden farklı semboller geliştirmiştir (Fink, 1996) (Bkz. Tablo 1). 
Tablo 1

Psikolojik Faktörler ve Kullanılan Semboller

\begin{tabular}{ll}
\hline Sembol & Psikolojik Faktör \\
$\mathrm{S}_{1}$ & Temel Gösteren \\
$\mathrm{S}_{2}$ & Bilgi \\
$\mathrm{a}$ & Küçük a nesnesi \\
$\$$ & Bölünmüş özne
\end{tabular}

İlk psikolojik faktör olan Temel Gösteren $\left(S_{1}\right)$ kavramını anlamak için, Lacan'ın dil kuramına göz atmakta fayda vardır. Lacan öznenin psişik yapısının üç düzen arasında bölünmüş olduğunu öne sürmüştür. Bu düzenler gerçek, imgesel ve sembolik olarak adlandırılmaktadır (Hill \& Leach, 1999). Sembolik düzen özneler arası ilişkileri ve dili kapsadığı için burada birincil odak noktası olacaktır. Gösterenler zinciri bu düzenin ana özeliklerindendir. Lacan bir gösterenin (her hangi bir kelime, ses veya görüntü) bir gösterileni (bir kavram ya da anlamı) temsil ettiğini ve bu ilişkinin gösterenler zincirini oluşturduğunu belirtmiştir. Ayrıca Lacan'a göre bir gösterilen başka bir gösterilen için gösteren de olabilir ve sembolik düzen bu bitmeyen gösterenler zincirinden oluşmaktadır. Ancak bu düzenin işlemesi ve iletişimin meydana gelebilmesi için bu akışın temel gösterenler arayıcılığıyla durdurulması gerekmektedir (Leader \& Groves, 2013). Temel gösteren ise bütün diğer gösterenlere anlam verendir ve içinde hem göstereni hem de gösterileni barındır. Öznenin özdeşim kurduğu, ya da karşı olduğu ve pozitif ya da negatif değere sahip olan her hangi bir gösteren olabilir. Temel gösteren sadece güçlüdür, gücü için her hangi bir gerekçeye ihtiyaç duymaz. Bu nedenle ona bir mantık aramadan, bir şey daha iyi olacağı için değil, sadece o öyle söylediği için uyulması gerekmektedir. Bazı genel temel gösterenler Atatürk gibi politik liderler, tanrı, şeytan, cennet, cehennem, özgürlük, demokrasi, Türk, İslamiyet, komünizm ve birçok benzer kelime olabilir. Kısacası, temel gösteren iletişimin yürütülebilmesi için kilit nokta olduğundan söylemlerin oluşumunu ve anlaşılmasını da sağlayan temel unsurdur (Fink, 1996).

İkinci psikolojik faktör olan Bilgi, temel gösterenlerin hedef aldığ gösterenler zincirin tümü olan dilin sistematik yönüdür. Lacan bilgi derken sadece öznenin bilinçli olarak bildiklerini değil aynı zamanda bilinçdışı bilgiyi de kastetmiştir. Psikanalizin de temel amacı bilinçdışı bilgiyi keşfetmektir. Ancak bilginin ne anlama geldiği farklı söylemlerde farklı işlevlere hizmet edebildiği için söylem içinde okunduğunda en iyi şekilde anlaşllabilmektedir (Fink, 1996).

Bölünmüş Özne (\$) kavramının da S harfi özneyi temsil ederken, üzerindeki çizgi ise öznenin bilinç ve bilinçdışı arasında bölünmüşlüğünü temsil etmektedir (Bracher, 1994). Lacan'a göre bir çocuk konuşmaya başlaması ile sembolik düzene girmekte yani toplum kurallarını, aslında Büyük Öteki'nin kurallarını kabul etmeye başlamaktadır. Lacan tarafından tanımlanan bu süreç Freud tarafından tanımlanan fallik sürece özdeştir denilebilir (Apollon, 2002). Büyük ötekinin kurallarını kabul eden çocuk toplumun bir parçası olmayı başarabilirken, aynı zamanda kendi ihtiyaç ve arzularını da bu kurallara göre ifade edebilmeye ve yaşayabilmeye başlamaktadır. Öznenin bölünmüşlügü “yabancılaşma (bölünmüş olma duygusu)" diye adlandırılan bu sürecinin ürünüdür. $\mathrm{Bu}$ durum öznenin kendi içinden geliyor gibi görünenlerin aslında dışarıdan ve ötekilerden 
geldiğini, yani çocuğun kendi istek ve arzularına yabancılaşmaya başladığını göstermektedir. Sonuç olarak özne gerçek kendiliğinden ayrılmış ve bölünmüş bir özne haline gelmektedir (Fink, 1996). Lacan öznenin sembolik düzene girdiğinde sembolik bir "iğdiş" yaşadığını söylemiştir. Bu terim ilk olarak Freud'un oedipus kompleksini anlatması ile kullanılmıştır. Lacancı psikanalizde iğdiş terimi öznenin bir zamanlar bir bütün olduğuna; ama sonrasında Büyük Öteki tarafından iğdiş edilerek önemli bir parçasından ayrıldığına dair hissine işaret etmektedir. Bu noktada öznenin iğdiş oluşu sırasında geride bıraktığı kısmını temsil eden kü̈çük a nesnesi (a) terimi devreye girmektedir. Özne kendini Büyük Öteki tarafından bölünmüş hisseder fakat aynı zamanda parçalanmamış bir bütün olmayı, dolayısıyla eksik olan neyse onu bulmayı arzular. Özne bu arzusunu açıklayabilmek için gerçek bir özne ile özdeşleşmek ister ve bu arzusunu küçük $a$ nesnesine atfeder. Yani küçük $a$ nesnesi, öznenin arzusunun nesnesidir ve tüm arzularına neden olan eksikliği tanımlar. Lacan, bu nesnenin gerçek bir nesneden ziyade bir fantezi nesnesi olduğuna ve öznenin kendisi dışında her şey olabileceğine dikkat çekmektedir. Arzunun nedeni olan bu nesnenin aynı zamanda her zaman arzulanabilir olabilmesi için her daim eksik ve ulaşılmaz kalması gerekmektedir (Bracher, 1994; Schroeder, 2008).

Daha öncede belirtildiği gibi Lacan Psikanalizin Diğer Tarafı seminerinde (Miller, 1991/2001), bu dört psikolojik faktörün farklı yapılanmalarından oluşan efendi, üniversite, histerik ve analistin söylemi olmak üzere dört farklı söylem geliştirmiştir. Lacan söylemler kuramına diğer üç söylemin de gelişmesinin başlangıcı olan efendinin söylemini oluşturarak başlamıştır. Temel gösteren, $S_{1}$, baskın konumdadır ve bölünmüş özneyi, $\$$, gösterenler zinciri, $S_{2}$, için temsil eder. Öznenin gösterenler tarafindan tam olarak temsil edilmesi mümkün olmadığı için, bu söylemin sonucunda öznede temsil edilemeyen bir kayıp, yani gösterilenler zincirinde temsil edilemeyen küçük $a$ nesnesi elde edilir. Bu söylem bölünmüş öznenin yapısını bize tarif eden söylemdir. Şekil 3’te Lacan'ın bu söylemi daha önce söz edilen dörtlü matriste nasıl gösterdiği görülmektedir.

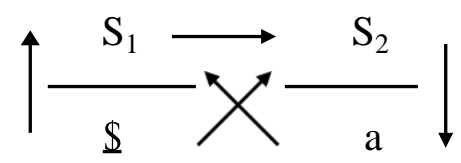

Şekil 3. Efendinin söyleminin dörtlü matriste gösterimi.

Geriye kalan üç söylemden efendinin söylemindeki her bir psikolojik faktörün saat yönünün tersine rotasyonu ile elde edilmektedir. Bir saat yönün tersine rotasyon ile üniversitenin söylemi elde edilir. Bu söylemde bilgi, $S_{2}$, fail konumundan bir kayba, eksikliğe, a, yönelir ve bilgi ve hakikat arasında bölünmüş, kendi öznelliğini bastırmak zorunda olan bir özne, $\$$, bir öğrenci yetiştirir (Bkz. Şekil 4).

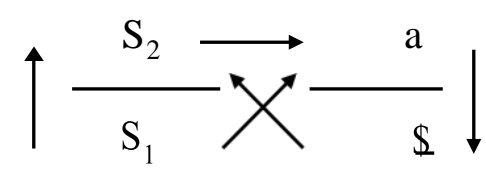

Şekil 4. Üniversitenin söyleminin dörtlü matriste gösterimi. 
Lacan üçüncü olarak histeriğin söylemi ve son olarak da analistin söylemini geliştirmiştir. Ayrıca, histeriğin söylemi ancak analistin söyleminin geliştirilmesi ile tam olarak kavranabilir olmuştur (Schroeder, 2008). Bu söylemler ve içerikleri bu makalenin ilerleyen kısımlarında daha detaylı olarak tartışılacaktır.

\section{Terapi Süreci Bağlamında Lacancı Söylem Kuramı}

\section{B. Hanım Vakası}

B. Hanım, 40 yaşında, dört yıllık evli ve iki yaşında bir oğlu olan bir kadındır. Hukuk Fakültesi mezunu olan B. Hanım bir devlet üniversitesinde öğretim üyesi olarak çalışmakta ve bir hukuk danışmanlığı bürosu işletmektedir. Danışan Ayna Klinik Psikoloji Destek Ünitesi'ne öfke kontrolü problemi ve yetersizlik hisleri şikâyetleri ile başvurmuştur. Kendisi ile haftada bir kere olmak üzere toplam 30 seans yapılmış ve terapi süreci sonlandırılmıştır. Daha önce bu şikâyetler ile ilgili herhangi bir psikolojik ya da psikiyatrik yardım almadığı öğrenilen B. Hanım'ın, yedi yıl önce yaşadığ1 romantik ilişki problemleri ile ilgili birkaç kez bir psikiyatr ile görüştüğü öğrenilmiştir. Danışan kendisinin hep sinirli birisi olduğunu; ama oğlunun doğumu sonrası öfke kontrolünde zorlanmaya başladığını dile getirmiştir. B. Hanım, öfke kontrol problemini, oğluna kahvaltıda, uyurken ya da evden çıkacağı zaman en ufak bir aksilik çıkardığında bağırması ve eşine de yersiz yere ya da önemsiz konularda sesini yükseltebilmesi olarak tarif etmiştir. Örnek olarak "Mesela 'Onu oraya neden koydun!' diye bile sinirlenebiliyorum.” demiştir. Danışan oğlunun tahmin ve kontrol edilemez olduğunu, her an her yerde bir aksiliğe sebep olabildiğini söylemiştir. Oğlunun onun planlarını bozma ihtimalinin kaygı seviyesini yükselttiğini belirten danışan, nitekim işler onun planladığı gibi gitmediğinde öfkelendiğini ifade etmiştir. B. Hanım, aynı zamanda iyi anne olamamakla ilgili yetersizlik kaygıları yaşadığını belirtmiştir. Danışanın yetersizlik kaygılarının sadece bu alanda değil, iş, evlilik gibi daha birçok alanında da baş gösterdiği görülmüştür.

B. Hanım'la yürütülen terapi sürecinin başlarında danışanın öfke problemine odaklanılmış, öfkenin çıktığı yerler, danışanın hayatına olan olumsuz etkileri ve öfkesinin altında yatan sebepler araştırılmıştır. B. Hanım'ın öfkesini çocukla beraber artan stresine bağlamış olması nedeni ile çocuk sahibi olmakla ilgili doğum öncesi, sırası ve sonrası duygu, düşüncelerine odaklanılmıştır. Danışanın öfke kontrol probleminin de yetersizlik hisleri ile alakalı olduğu düşünülmüştür. B. Hanım iyi bir anne olamadığına dair düşüncelerinin kaygı seviyesini yükselttiği ve sonuç olarak bu kaygılarını öfke olarak dışa vurulduğu düşünülmüştür. Eleştirel bir anne tarafından yetiştirilen danışanın, annesinin ablasını "hanım hanımcık" diye betimlerken kendisine "çalı süpürgesi" dediğini anlatmış ve bunun kendisinde yetersizlik hisleri gelişmesine sebep olduğu düşünülmüştür. Danışanın yetersizlik hisleri ile hayatındaki her şeyin kontrolünde olarak baş etmeye çalıştı̆̆ düşünülmektedir. Ayrıca, danışanın annesinin tersine babası ile olan ilişkisinde daha çok sevildiğini ve iki kardeşine tercih edildiğini hissettiği öğrenilmiştir. Ancak sevginin ve değerin alındığı kaynak olan babanın alkol bağımlısı olması ve çocuklarına duygusal şiddet uygulamasının, sevginin yanında babadan korkuyu da getirdiği düşünülmektedir. Babayla ilişkide yaşanan belirsizliğin ve ikircikli duyguların kontrol etme arzusunun temellerini oluşturduğu izlenimi edinilmiştir.

B. Hanım ayrıca yedi sene önce yaşadığı bir romantik ilişkisi ile ilgili de konuşmak ve farkındalık kazanmak istediğini belirtmiştir. İlişki yaşadığı ve “o adam” diye söz ettiği kişinin üniversitede yüksek lisans eğitimi sırasında asistanlık yaparken çalıştığı ve ders aldığı bir hocası 
olduğunu belirtmiş, bu adamın kendisinden 20 yaş büyük ve evli olduğu, ilişkinin 10 yıl sürdüğü öğrenilmiştir. Danışan bu ilişkiyi "yasak ilişki” olarak tanımlamış ve "Yaşarken çok tutkulu ve anlamlıydı ama şimdi düşündüğümde 'Korkunç bir şey yapmışım.' diyorum.” demiştir. B. Hanım ilk cinsel birlikteliğini de o kişiyle yaşadığını ve bu yüzden de bu ilişkinin o zaman kendisi için çok şey ifade ettiğini 1srarla dile getirmiştir. Danışan o kişinin eşinin ve çocuklarının olduğu eve eşi ilişkilerini bildiği halde gittiğinden, o kişi istiyor diye başka erkeklerle birliktelikler yaşadığından ve başka sevgilileri de olduğunu öğrendiğinde "Benim için senin yerin ayrı." dediği için bunu önemsemediğinden bahsetmiştir. Hocası derste onu övdüğü, takdir ettiği için ondan etkilendiğini belirtmiş, sonrasında da evli olmasına rağmen onu tercih ettiği için ve değerli ve onun gibi güçlü birinin yanında kendisini de güçlü ve statü sahibi hissettiği için bu ilişkiyi sürdürdüğünü düşündüğünü ifade etmiştir. Bu durum danışanın fallik süreçte yaşadığı bir takılmadan ve diğer kadınları aslında anneyi yenerek babayı elde etme arzusundan kaynaklı olarak değerlendirilmiştir.

Terapinin başından sonuna kadar olan bütün süreçte B. Hanım, terapistten çocuğunu nasıl yetiştirmesi gerektiği, onu memeden nasıl kesebileceği, yataklarını nasıl ayırabileceği, uyku problemini nasıl çözebileceği, yemek problemleri vb. birçok konuda bilgi ve yönlendirme istemiştir. S1k sık sorunlarının nedenlerinin ne olduğunu tam olarak anlamak istediğini dile getirmiştir. Terapist çocuk yetiştirme ile ilgili konularda araştırmalar yapmış, bilgi edinmeye çalışmış ve danışanın bu konularda bilgilendirmiştir. Ancak, danışanın bilgi ihtiyacının hiç bitmediği, aynı konularla ilgili tekrar tekrar bilgi istediği gözlemlenmiştir. B. Hanım'la içinde bulunan sürecin bir psikanaliz değil terapi süreci olduğunu belirtmekle beraber, geçmişe yönelik bir değerlendirme yapıldığında bu örüntü, danışanın "histeriğin söylemi” içinde olduğunu düşündürmüştür. Dolayısıyla, bu makalenin devamında B. Hanım vakasından örneklerle histeriğin söylemi kavramı tartışılmıştır. Bu noktada, histeriğin söylemi teriminin kullanılmasının yaratabileceği karışıklığa değinmekte fayda olacaktır. Şöyle ki, Lacan adında histerik geçmesine rağmen bu söylemin sadece histerik yapıdaki danışanlarda görülmediğine ve her histerik yapıdaki danışanın da bu söylem içinde bulunmayacağına dikkat çekmiştir (Fink, 1996). Dahası, bu söylem sadece analiz içinde gözlemlenen bir söylem de değildir. Aksine bu söylem konuşan her öznenin söylemidir, dolayısıyla terapiye şikâyetlerle gelen danışanın da söylemidir (Verhaeghe, 1995).

Diğer yandan, Lacan, bu söylem öznenin arzusunun dile döküldüğü tek söylem olduğu için analitik deneyimin yaşanabilmesi için analizanın söyleminin "histerikleşmesinin" ön koşul olduğunu iddia etmiştir (Wachman, t.b.).

\section{Histeriğin Söylemi}

Histeriğin söyleminin öne sürülen dört pozisyon içinde nasıl yapılandığını gösteren dörtlü matris şu şekildedir (Bkz. Şekil 5):

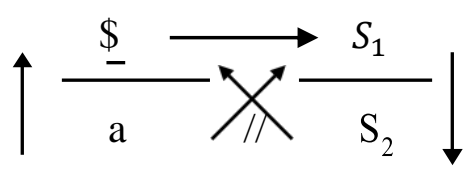

Şekil 5. Histeriğin söyleminin dörtlü matriste gösterimi. 
Lacan histeriğin söyleminde, şimdiye kadar her söylemde söyleme maruz kalan ve pasif konumda olan bölünmüş özneyi, \$, fail konumuna, yani en baskın ve aktif konuma koymuştur. Aslında, bölünmüş özne şimdiye kadar efendi ona emir verip, üniversite onu öğrenci olarak yetiştirir ve analist onu sorgularken, sonunda sesini duyurabilir olmuştur (Verhaeghe, 1995). Daha önce de belirtildiği gibi, Lacan öznenin konuşmaya başlaması yani sembolik düzene girmesi ile gösterenler tarafından bölündüğünü söylemiştir, dolayısıyla bu söylemin konuşan her varlığın söylemi olduğunu söylenebilir. Lacan aynı zamanda bu bölünmüş özenin birincil nesnesini kaybettiğini ve bunun kaybedilen özneyi bulmak için hiç bitmeyen bir arzuya sebebiyet verdiği öne sürmüştür (Quackelbeen vd., 1994). Bölünmüş öznenin bu arzusu karşıdan bir talep olarak kendini gösterecektir (Schroeder, 2008). Yani Lacan'a göre histeriğin söyleminde en çok kullandığı cümle bir cevabın talep edildiğini gösteren ve karşıdan bir cevap almasını sağlayacak "Söyle bana!" olacaktır (Wachman, t.b.). Aslında kişi ötekine eksikliğini doyurması ve bölünmüşlügünü iptal etmesi için "Bana mükemmel olmak için ne yapmam gerektiğini söyle." şeklinde seslenmektedir (Soysal, 2006). Benzer şekilde, terapi süreci boyunca B. Hanım'dan “Bana söyler misiniz?” ile başlayan birçok cümle duyulmuştur. Örneğin, danışan birçok kez "E. Hanım, lütfen bir yol gösterin! Nasıl daha iyi bir anne olabilirim, memeden kesmek için ne yapsam, odasını ayırırken nasıl bir yol izlesem?", "Benim bu annem ve babamda olan problem ne, nelere yol açtı yanlış davranışları?”, "Bu öfke problemin nasıl aşacağım?”, “O adamla ilişki yaşamamın bir sebebi var mı?” ya da "Ben neden böyle davranıyorum, ne neden oluyor buna?” vb. cümleler kullanmıştır.

Bu söylemde hitap edilen Öteki, $\mathrm{S}_{1}$, analist, terapist, öğretmen, doktor, din adamı ya da eş olabilecek olan Büyük Öteki'dir (Bracher, 1994). Aslında histeriğin söyleminde kişinin talebine ve sorularına cevap veren herhangi biri efendi yani Büyük Öteki olabilir. Histeriğin söyleminde efendi bildiği varsayılan ve cevapları üretmesi beklenen kişidir (Fink, 1996). B. Hanım ile olan ilişkide açık şekilde terapist Büyük Öteki pozisyonunu almıştır. Terapist, danışanın ilk sorusuyla beraber çocuk gelişimi ve bakımı ile ilgili yeterli bilgisi olmadığını ve danışanın bu konularda daha çok tecrübe sahibi olduğunu söylemiş olmasına rağmen, B. Hanım terapistin uzman kişi olduğunda dolayısıyla kendisinden daha iyi bileceğinde ısrar etmiştir. Sonuç olarak da terapist, çocuk bakımıyla ilgili kitaplar okumuş, araştırmalar yapmış, dolayısıyla bu konuda bilgi edinmiş ve danışanın sorularına cevap vermeye çalışmaya başlamıştır. Bu durum histeriğin söyleminde sonuç olarak nasıl bilginin, $S_{2}$, üretildiğini gösterir niteliktedir (Schroeder, 2008). Fail olan B. Hanım, efendiden yani terapistten bilgisini göstermesini ve gücünü kanıtlamasını istemiş, sonuç olarak da terapist kendini bu konuda bilgi dolmuş ve danışana yol gösterir haldebulmuştur.

Fakat sorularına cevap alması ile birlikte histerik özne ötekini onu sakinleştirebilecek sonsuz bilgiye sahip öteki konumuna yükseltir (Wachman, t.b.). Benzer şekilde, B. Hanım da terapistin sorularına cevap vermesi ile daha çok bilgi talep etmeye başlamıştır. Danışanın sorularının içeriği değişmeye başlamış ve oğlunun psikolojisine zarar vermek, eşi ile olan ilişkisinin bozulması, işteki sorunlar gibi birçok konuya dair endişelerini yatıştırabilecek cevaplar almaya çalışmıştır. Her seansa oğlu, kocası, işi, ailesi vb.ile ilgili başka bir kaygı krizi içinde gelmeye başlamıştır. Mesela geç kaldığı bir seansa ağlayarak gelmiş ve oğlunun o evden çıkarken ağlama krizine girdiğini, kendisini bırakmak istemediğini, o yüzden evden vaktinde çıkamayıp geç kaldığını anlatmıştır. Ağlayarak "Onun bana ihtiyacı var bu ihtiyaç benim işimden her şeyimden daha önemli. Onu öyle bırakıp evden çıkmak zorunda olduğum için hep suçlu hissediyorum. Bu sabah ilk kez başımıza 
gelmedi bu son da olmayacak biliyorum. Çok yoruldum, o böyle kriz halinde ağlayınca da elim ayağıma dolaşıyor, ben de ağlıyorum, Ne olur bir yol gösterin artık katlanamıyorum. Nasıl susturabilirim onu, ne yapsam ona zarar vermem?" demiştir. O seans terapist danışanın sakinleştirmek için neden bu kadar kaygılı olduğuna odaklanmış ve ayrıca bu kriz hallerinde ne yapabileceği ile ilgili bilgi vermiştir. Başka bir seans B. Hanım'ın eşi ile olan sorunlarını anlatması ile başlamış, danışan kocasına devamlı bağırıyor, söyleniyor ve onu azarlıyor olmaktan dolayı kendini çok suçlu ve utanç içinde hissettiğini ifade etmiştir. Kocasının önceden sakin kalabilirken artık onun da sabrının tükendiğini ve sinirlenmeye başladığını belirtmiş, ağlayarak "Hep benim suçum, daha fazla katlanamayacak bana. Daha sakin olmak zorundayım yoksa onu kaybedeceğim." demiştir. B. Hanım'la yaşanan bu örnekler Lacan'ın Büyük Öteki'nin histeriğin söyleminde kaygıları yatıştırmada yardımcı olacak güven verici ve sakinleştirici bilgiler veren kişi olmasının bekleneceğine dair görüşünü destekler niteliktedir (Bracher, 1994).

Diğer yandan Lacan'a göre, ötekinin soruları ile bilgi üretmesini sağlayan histerik söylemdeki özne, hep daha fazlasını isteyecek, ötekinin limitlerini zorlayacak ve verilen bilginin yetersiz ya da yanlış olduğunu kanıtlamaya çalışacaktır (Fink, 1996). Daha öncede belirtildiği gibi, terapistin danışanın sorularını cevaplamaya, yetersizlikle ilgili endişelerini anlamaya ve yatıştırmaya çabalamaya başlaması ile B. Hanım, her seansa farklı bir problem ve yeni bir kaygı krizi içinde gelmeye başlamıştır. Oğluna dair paylaştığı ilk problemi öfke krizleri olmuş, sonra memeden kesme, uyku sorunları, çocuğun odasını ayırma, son olarak da kreşe başlatma problemleri ile seanslara gelmiştir. Danışan, verilen önerilerden hiçbir zaman tatmin olmamış ve örneğin "Denedim ama olmad1, sabah ben çıkarken yine ağladı bugün.", "Hala emmek istiyor, nasıl ayıracağız bilemiyorum.” demeye başlamıştır. Bu sırada B. Hanım, her yeni problemlerle beraber terapistin bilgisinin sınırlarını zorlamaya ve bir süre sonra terapinin faydasını sorgulamaya başlamıştır. Bu doğrultuda Wacjman (t.b.), histerik söylemdeki kişinin psikoterapi ilişkisi içerisinde terapistin sorularını cevaplamasını, bir tanı koymasını ve tedavi önermesini talep edeceğini; ancak, hemen bir seans sonrasında bile tamamen iyileşmediği, tanının yanlış olduğunu ya da terapinin işe yaramadığını söyleyerek terapisti eleştirebileceğini söylemiştir. Benzer örüntü B. Hanım'la yapılan seanslarda danışanla yetersizlik hisleri ve öfke problemine dair yapılan yorumlar ve formülasyonlardan sonra gözlemlenmiştir. B. Hanım "Bütün bu sorunlara tam olarak ne neden oldu gerçekten bilmek istiyorum, annem mi babam mı yoksa ne?" diyerek daima problemlerinin nedenlerine dair kesin açıklamalar istemiştir. Terapist zaman zaman yorumlar yaptığında o seans içinde yapılan yorumları anlamlandırabilmiş, geliştirici yorumlar yapıp örnekler verebilmiş olmasına rağmen, bir sonraki seansta "Ben düşündüm de tam olarak sizin söylediğiniz gibi değil." ya da "Söylediklerini tam olarak benim durumuma uymuyor." demiştir. Benzer şekilde seanslara getirdiği bir problem ebeveynleri ile olan ilişkisi üzerinden ele alındığında, mesela terapist annesiyle olan ilişkisine dair bir yorum yaptıysa babasıyla daha alakalı olduğunu düşündüğünü söylemiştir. B. Hanım, ayrıca eşi ile yaşadığı ilişki problemlerini çözmek için öneriler istemesi üzerine seanslarda ilişki içindeki dinamiklere odaklanılmış ancak danışan kocası ile ilişkisinin iyiye gitmektense gün geçtikçe daha içinden çıkılmaz hal aldığını belirtmeye başlamıştır. B. Hanım işte yaşadığı, işleri yetiştireme, kendini yetersiz hissetme gibi şikâyetlerle geldiğinde, danışanın yetersizlik hisleri üzerinde durulmuş, kendine başarmak için küçük hedefler koymasının faydası konuşulmuş ve işte yolunda giden şeylere de dikkat çekilmiştir. Danışan bu seanstan farkındalık 
kazanarak ve davranış değişikliğine gitmeye karar vererek çıkmıştır. Ancak sonraki seanslarda yapması gereken işleri yine yetiştiremediğinden yakınmıştır. Bir süre sonra da terapiden çok fayda görmediğini söyleyerek iki haftada bir seans yapmayı talep etmiştir.

Fink (1996) bu sürecin efendinin kendini yetersiz ve iğdiş edilmiş hissetmesine neden olabileceğini öne sürmüştür. Böylelikle, histerize olmuş özne ile analist arasındaki bu bitmek bilmez mücadele, sonuç olarak kişiler arası ilişkide öznenin tatmin olmaz arzusunu göz önüne çıkarır. Kendini iğdiş edilmiş hisseden analist, B. Hanım'la yaşanan süreçte de terapistin yaşadığı gibi daha çok bilgi üretmeye çalışır (Verhaeghe, 1995). Bu bağlamda Lacan, histeriğin söyleminin bilimsel bilginin kaynağı olduğunu öne sürmüş̧ür. Nitekim Freud da psikanalitik teoriyi histerik hastalarının karşısında bilgisinin yeterliliğini kanıtlamaya çalışırken oluşturmuştur (Breuer \& Freud, 1895; Fink, 1996). Benzer şekilde, B. Hanım'la girilen her mücadelenin sonunda terapist, kendi bilgisinin yetersiz olduğunu düşünmüş, kendisinin danışana yetemediğini düşünerek yetersiz hissetmiş ve danışanı bu konularda daha bilgili olduklarını düşündüğü uzmanlara yönlendirmiştir. Örneğin, terapist, kendisinin aynı zamanda eğitimi sırasında ders aldığı ve hocaları olan, dolayısıyla ondan daha iyi bildiklerine inandığı bir çocuk psikologu ve aile terapistine yönlendirme yapmıştır. $\mathrm{Bu}$ örüntü histerik söylem içindeki bir danışanla karşı karşıya olan terapist/analist için kaçınılmaz bir süreçtir. Histerik analist, terapist, öğretmen, doktor ya da eşi olabilecek efendiyi bilgisinin eksikliğinin görüleceği noktaya kadar sürükler (Bell,2014).

Ne var ki B. Hanım önerilen kaynakları hiçbir zaman kullanmamış ve bu konularda şikâyet etmeye devam etmiştir. Bu sürecin sonrasındaki seanslardan birine danışan ağlayarak gelmiş ve her şeyin ne kadar da kötüye gittiğinden yakınmaya başlamıştır. Oğlunu kontrol etmekte hala zorlandığını, sinirlerine hala hâkim olamadığını, eşi ile kavgalarının devam ettiğini ve işte de üstüne düşenleri hala yapmadığını söylemiştir. Seansın ilk 20 dakikası danışanın hayatında kötü giden şeylerden yakınması ile geçmiş, bu sırada terapiste birçok soru sormuş ama yanıtlamasına izin vermemiş ya da cevapları dinlememiştir. Terapist bu süre boyunca terapinin işe yaramadığını düşünerek hayal kırıklığı yaşamış, kendinin iyi bir terapist olmadığını ve danışana yardım edemediğini düşünmüştür. Aynı zamanda danışana elinden gelen her şeyi yaptığı halde şikâyet etmeye devam ettiği ve üstelik diğer uzmanlara başvurmadığı için de kızgın hissetmiştir. Sözü geçen seansta, aslında bu örüntünün danışanın hayatındaki annesi, babası, kocası ve kız kardeşi olabilecek diğer Büyük Ötekilerle olan ilişkilerinde de olduğu görülmüştür. B. Hanım'la, yaşadığı kaygı durumu halinde, terapiste ondan onun endişelerini yatıştırmasını beklediğini hissettirdiği fakat buna da izin vermediği ya da terapistin çabalarının yetersiz kaldığı gözlemi paylaşılmıştır. Danışan bunun üzerine aynı şeyleri ebeveynlerinden, kız kardeşinden ve eşinden de devamlı duyduğunu dile getirmiştir. Saydığı bu kişilerle de devamlı sorunlarını paylaşan, öneri ve yardım isteyen danışan onlarında önerileri yani söylemi sonucu üretilen bilgiyle hiçbir zaman tatmin olamamaktadır. Bu durum çevresindeki kişilerin yetersiz hissetmesi ile öfkelenmelerine ve B. Hanım'dan şikâyetçi olmalarına neden olmaktadır. Örneğin danışanın kız kardeşinin danışan hakkında 'B.'nin derdi bitmez, devamlı bizi yoruyor ve darlıyor bu dertleriyle. Ne yapsak yaranamıyoruz ki!’ dediği öğrenilmiştir.

Bölünmüş öznenin fail, temel gösterenin öteki, bilginin ise bölünmüş öznenin Büyük Ötekinden talebi olarak üretilen konumda olduğu histeriğin söyleminde, küçük a nesnesi hakikat konumundadır. Bu histeriğin söylemindeki öznenin arzusunun birincil kayıpla alakalı olduğu 
anlamına gelmektedir. Öznenin en çok kullandığı cümle olan "Söyle bana!” aslında "Bana kim olduğumu, arzumun ne olduğunu söyle!"'dir (Wajcman, t.b.). Bu bağlamda söylem matrisini tekrar oluşturmak gerekirse (Bkz. Şekil 6):

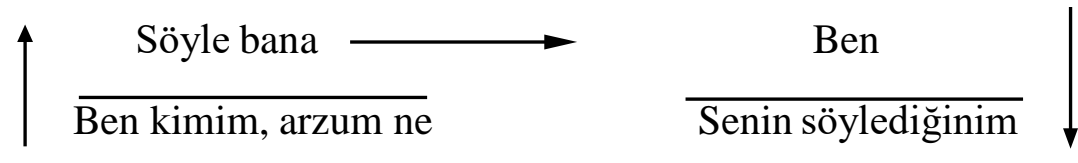

Şekil 6. Histeriğin söyleminin dörtlü matriste diğer bir gösterimi.

Ancak, bu söylemin ürünü yani Büyük Öteki tarafından verilen cevaplar, hakikat kelimelerle ifade edilemeyeceği için her zaman hakikatten çok uzakta olmaya mahkûmlardır. Bu süreç söylemler kuramındaki kopukluklar kavramı ile açıklanmaktır ve tam olarak bu kopukluklar histerize özne ile Büyük Öteki arasındaki bitmek bilmeyen mücadeleyi doğurur. Bu imkânsızlıklardan dolayı üretilen her bilgi öznenin arzu nesnesinden biraz daha uzaklaşmasına sebep olacak ve öznenin biraz daha kendi gerçek arzusunda yabancılaşması ile sonuçlanacaktır (Verhaeghe, 1995). Paradoksal olarak, histerik söylem içindeki bir danışan ile karşı karşıya kalındığında izlenebilecek iki yol vardır: danışanın sorularına cevap vermek ve bilgi üretmek ya da hakikati konuşmak ve soruları cevaplamamak. Dolayısıyla psikanalitik teori, bilgi üreterek hakikate, yani ancak kendi kendine konuşarak bilmeceyi çözmemizi sağlayabilecek gerçek bilgiye yani bilinçdışına ulaşmanın mümkün olmadığını öne sürmüştür (Moncayo, 2008). Freud, bunu serbest çağrışıma izin vererek başarmayı çalışırken (Breuer \& Freud, 1895), Lacan da analistin histeriğin talebine cevap vermediğini yeni bir pozisyon olan analistin söylemi kavramını geliştirmiştir.

\section{Analistin Söylemi}

Lacan'a göre histeriğin söyleminde özne analistin sorularına cevap vermesini isterken, analist analizanın arzusunu sorgulamalıdır. Bu manevra analistin söylemine geçişin yoludur. Fakat şunu söylemekte fayda vardır ki, bu her analistin bu söylemi benimsiyor olduğu anlamına gelmemektedir. Bir analist üniversite, efendi ya da histeriğin söylemi içinde de olabilir (Fink, 1996). Bu nedenle analistin söylemini Lacan analitik deneyimden ayırır ve analistin söyleminin histeriğin söylemindeki hakikatinin ses bulabileceği söylem olarak formulize eder (Bracher, 1994). Bu nedenle histerik söylem içinde olan bir danışana karşı arzunun sorgulamasında yol gösterici olabilecek analistin söylemine de kısaca değinilmesinde fayda olacaktır. Analistin söyleminin nasıl yapılandığını gösteren dörtlü matris şu şekildedir (Bkz. Şekil 7):

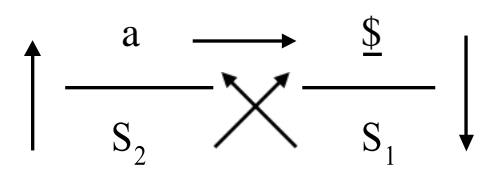

Şekil 7. Analistin söyleminin dörtlü matriste gösterimi. 
Küçük $a$ nesnesi analistin söyleminde fail konumundadır, dolayısıyla_analist kayıp olan arzu nesnesi yerine geçer ve bölünmüş nesneyi arzusuyla yüzleşmekle karşı karşıya bırakır. Analizanın konuşma sırasında farkına varmaksızın ürettiği gösterenler, arzu nesnesinin etrafında dönmektedir (Soysal, 2006). Lacan'a göre analistin aktif bir şekilde konuşmak yerine dinlemesinin de nedeni budur. Bu yolla analizanın analistin temsil ettiği boşluğu konuşarak arzusu ile doldurması amaçlanır. Analist, arzuyu canlı tutmakla beraber, bu arzu nesnesi çevresinde dönen gösterenlere odaklanmaktadır. Bölünmüş özne, \$, öteki konumundadır ve analist öznenin bilinç ve bilinçdış1 arasındaki bölünmüşlügünü sorgulamayı, öznenin arzusunu fark etmesini ve isimlendirebilmesini amaçlar. Diğer bir deyişle, analist bastırılmış olan hakikati sorgulamaya ve bulmaya çabalar (Bracher, 1994; Fink, 1996, Schroeder, 2008). Lacan, hakikate yani bilinçdışı arzuya ilişkin esas bilgiyi verecek olanın analizanın konuşması olduğunu ve bunun ancak analizanın kendi duygu ve düşüncelerinin ifadesini içeren "tam konuşma" ile mümkün olabileceğini söylemiştir (Moncayo, 2008). Bu doğrultuda, analizanı dinleyerek elde edilecek olan analizanın bilinçdışı bilgisi, $\mathrm{S}_{2}$, analist söyleminde hakikat konumundadır (Schroeder, 2008). Bilinçdışına dair ipuçları aynı zamanda dil sürçmesi, konuşma sırasındaki gevelemeler, rüyalar, acemi ve niyetsiz yapılan eylemlerin görüldüğü anlarda da bulunabilir (Fink, 1996). Lacan, ayrıca analistin konuştuğu zaman öznenin arzusunu çıkarmasında yardımcı olmayı amaçlaması gerektiğini söylemiştir. Analistin konuşması, aktif yorum yapmasının yanında analizanın konuşmasının bir kısmının vurgulanmasını ya da Lacan tarafından önerilen seans sürelerin değişkenliği olarak önerilen seansların kesilmesini de içerir (Moncayo, 2008).

Öznenin bölünmüşlüğünü sorgulayan analistin söylemi sonucu üretim, Büyük Öteki tarafından dayatılan temel gösterenler yerine öznenin kendisi tarafından yeniden inşa edilen yeni temel gösterenlerdir. Öznenin kendi yeni temel gösterenleri, $S_{1}$, henüz her hangi başka gösterenler ile bağlantısı olmayan, öznenin nihai değerlerini, varlığını ve kişiliğini oluşturacak olan gösterenlerdir. Diğer bir deyişle, analistin söylemi daha az baskıcı, kayıtsız şartsız kabul bekleyen, katı ve sert ve daha açık ve değişken temel gösterenlerin oluşturulmasını amaçlar (Moncayo, 2008). Analist, karşısına semptomlarıyla gelen özneye, çoğu terapide olduğu gibi onu belirleyecek ya da onaracak nesneyi sunmaktan ya da öğ̈̈tlemekten olabildiğince uzak durur bir pozisyondadır. $\mathrm{Bu}$ yüzden de modern terapilerin çoğunda olduğu gibi bilen kişi konumuna geçerek eksikliği doldurmak yerine boşluğa yer bırakarak öznenin üstündeki çizgiyi-yarığı korumak, analitik çalışmanın çerçevesini belirler. Amaç özneyi arzulamaya iten bu eksikliği onarmak yerine bununla birlikte yaşayabilmesinin olanağını sağlamaktır (Soysal, 2006).

\section{Sonuç}

Danışan ve terapist arasındaki ilişki terapi sürecinde önemli bir role sahiptir (McWilliams, 2013). Lacan'1n söylem kuramına göre, söylemler konuşulan kelimelerden dahi önce gelir ve özneler arası ilişkilerdeki sosyal bağın niteliğini belirlerler (Fink, 1996). Dolayısıyla danışanın hangi söylem içinde olduğu aynı zamanda özneler arası bir ilişki olan terapi ilişkisinin niteliğini de etkileyeceği düşünülebilir. Söylemler kuramının temel bir avantajı da ikili ilişsilerdeki ifade edilenlerin yanında ifade edilmeyen yani bastırılan faktörlerin de ayırt edilebilmesini sağlamasıdır. Ayrıca, söylemlerin sonucunda üretilenin de ne olacağının görülmesini sağlar (Bracher, 1994).

Bu makalede, histerik söylem içinde olduğu düşünülen B. Hanım vakası terapi sürecinden 
örneklerle ele alınmıştır. Söylemler kuramına göre danışanın devamlı şikâyet halinde olması, sık sık sorular sorması, danışanın bu talebi karşısında terapistin problemlere ve sorulara yönelik bilgi verme çabası danışanın histeriğin söyleminin içinde olduğunu düşündürmüş̧ür. Terapist, süreç içerisinde B. Hanım'ın hiçbir zaman yaptıklarından ya da söylediklerinden tatmin olmadığını düşünmüş ve kendini yetersiz ve engellenmiş hissetmiştir. Histeriğin söylemi aslında terapide danışana yetemediğini hisseden terapistin duygularını açıklar niteliktedir. Histerize olmuş özneye verilen cevaplar hiçbir zaman öznenin hakiki arzusunu eş olamayacağı için hiçbir zaman da özneyi tatmin etmeyecektir. Dolayısıyla danışana cevap vermek yerine asıl arzusunu sorgulamak gereklidir, yani bu tatmin olmayan danışan karşısında terapistin ne yapmaması gerektiğini gösterir nitelikte olarak değerlendirilebilir. Analistin söylemi de tam burada devreye girer ve öznenin konuşması ile ortaya çıkacağı düşünülen bilinçdışı bilginin asıl cevap olacağını söyler ve bu bilgiyi elde edebilmek için izlenebilecek yola işaret eder.

Danışanın histerik söylem içinde olduğunun fark edilmesi ile terapist, danışana bilgi vermek yerine bu süreçteki danışanın tatminsizliği üzerinde durmuştur. Danışana cevap vermek yerine dinlemeye ve bilinçdışı arzusunun çıkabileceği noktalara odaklanmaya çabalamıştır. Ancak, B. Hanım'la içinde bulunan sürecin bir terapi süreci olduğu ve psikanalizin amaçlanmadığ göz önünde bulundurulmalıdır. Buna rağmen, söylem kuramı terapistin terapi ilişkisinde rol alan, bastırılan ve görünürde olan faktörleri ayırt etmesinde yardımcı olmuştur. Bu bağlamda, kesin sonuca varılması yeterince ele alınmadan terapi süreci bittiği için mümkün olmasa da, danışanın temel kaybı ile mücadele ettiği düşünülmüştür. Süreç boyunca, danışanın evli ve yaşlı eski erkek arkadaşına "baba" demiş olduğu rüyasını anlatmış olması, her probleminin babası ile ilişkisi ile olan bağlantılarını bulma çabası, annesiyle ilişkisi gündeme geldiğinde ısrarla odağı babası ile olan ilişkisine çekmiş olması dikkat çekmiştir. Ne var ki terapistin yorumlarının babasına yöneldiği seanslardan sonra, terapiye geç gelmek, duygularından bahsetmemek, fazla konuşmak gibi direnç niteliği taşıdığ1 düşünülen davranışlar gösterdiği gözlemlenmiştir. B. Hanım’la yapılan seanslarda, hayatındaki erkekler olan kocası ve oğlu ile ilişkisinde çıkan öfkenin onları kontrol etme çabası ile bağlantısı olduğuna dair yorumlar yapılmıştır. Kontrol çabasının babası ile ilişkisindeki duygusal belirsizlikten kaynaklı olabileceği konuşulmuştur. Sonlandırma seansından önceki son seansta ise danışan eski ilişkisini, babasını elde etme çabası olabileceğini fark etmiş, o kadar güçlü bir adamın onu babasını çağrıştırmış olabileceğini dile getirmiştir. Üstelik bunun en iyi kanıtının ona rüyasında "baba" diye seslenmiş olmasının olduğunu belirtmiştir. Bu ilişkide, diğer kadınlara tercih edilmenin de onu değerli hissettirdiğine dikkat çekildiğinde "Babayı annenin elinden çalmak gibi." demiştir. Bu bilgilere ek olarak danışanın annesinin danışanı "çalı süpürgesi” diye çağırıyor oluşu ve bu kelimenin "çalmak" kelimesi ile benzerliği dikkat çekmektedir. Süreçte danışanın söyleminde yer bulan bu bilgilerin danışanın bilinçdışına ilişkin bilgiler olduğu düşünülebilir. Bu bağlamda, danışanın bilinçdışına ensest yasağından dolayı bastırılan arzusunun ise "babayı anneden çalmak, onunla bir olmak” olduğu düşünülmüştür. Bastırılan bu arzu öznenin bölünmüşlüğünde kendini, kayg1, öfke ve kontrol etme arzusu olarak kendini göstermektedir denebilir. Dolayısıyla, analistin söyleminin danışana özgü gösterimi basitçe şu şekilde oluşturulabilir (Bkz. Şekil 8): 
Terapist
$\begin{aligned} & \text { rüya, çalı süpürgesi, çalmak, } \\ & \text { babayı anneden çalmak, } \\ & \text { baba ile bir olmak arzusu }\end{aligned}$

Şekil 8. Analistin söyleminin dörtlü matriste danışana özgü gösterimi.
Danışan (Kaygı, kontrol arzusu, öfke problemi)

Ensest yasağ1

Bu noktada danışanın ilk önce gerildiği sonra "Bu psikolojideki Oedipus Kompleksi değil mi?” diyerek normalleştirmeye çalıştığı gözlemlenmiştir. Bu seansın üzerine B. Hanım iki ay boyunca seanslara gelmemiş ve sonrasında terapiyi sonlandırmaya karar vermiştir. Bu karar danışanın direnci olarak değerlendirilmiştir. Benzer şekilde Lacan (Miller, 1998/1975), direncin Büyük Ötekinin yasasında girince bastırılmış olan arzunun söze gelmesi ile yani söylenemeyecek olanın söylendiği yerde çıktığını öne sürmüştür ki, B. Hanım'la yaşanan sürecin bu duruma bir örnek teşkil ettiği düşünülmüştür. 


\section{Kaynakça}

Apollon, W. (2002). After Lacan: Clinical Practice and Subject of Unconscious. New York: State University of New York Press.

Bell, S. (2014). Fragment of a Case of Posthysteria: D'or Owns the Jewel. ESC: English Studies in Canada, 40(1), 189-210.

Bracher. M. (1994). On the Psychological and Social Functions of Language: Lacan's Theory of the Four Discourses. Bracher, M., Alcorn, M. W., Corthell, R. J., \& Kenney, F. M. (Ed.), Lacanian Theory of Discourse: Subject, Structure and Society içinde (ss. 107-128). New York, London: New York University Press.

Breuer, J., \& Freud, S. (1955) Studies on Hysteria (J., Strachey, Çev.). (Özgün eser 1895 tarihlidir). New York: Basic Books.

Clemens, J., \& Grigg, R. (2006). Jacques Lacan and the Other Side of the Pscyhoanalysis: Reflections on Seminar XVII. Durham, London: Duke University Press.

Fink, B. (1996). The Lacanian Subject: Between Language and Jouissance. Princeton, New Jersey: Princeton University Press.

Hill, P., \& Leach, D. (1999). Lacan for Beginners. Danbury: For Beginners.

Lacan, J. (2001). The Seminar of Jacques Lacan: Book XVII, The Reverse Side of the Psychanalysis (C., Gallagher, Çev.). (Özgün eser 1991 tarihlidir).

Leader, D., \& Groves, J. (2013). Introducing Lacan: A Graphic Guide. North Road, London: Icon Books.

Marshall, J. L. (1994). The Subject of Discourse: Reading Lacan through (and beyond)

Poststructuralist Contexts. Bracher, M., Alcorn, M. W., Corthell, R. J. ve Kenney, F. M.

(Ed.), Lacanian Theory of Discourse: Subject, Structure and Society içinde (ss. 19-43). New York, London: New York University Press.

McWilliams, N. (2013). Psikanalitik tanı: Klinik süreç içinde kişilik yapısını anlamak. İstanbul: Bilgi Üniversitesi Yayınları.

Miller, J. A. (1998). The Seminar of Jacques Lacan, Book 1: Freud's Papers On Technique (J., Forrester, Çev.). Cambridge University Press. (Özgün eser 1975 tarihlidir).

Moncayo, R. (2008). Evolving Lacanian Perspectives for Clinical Psychoanalysis: On Narcissism, Sexuation, and the Phases of Analysis in Contemporary Culture. Finchley Road, London: Karnac Books.

Schroeder, J. L. (2008). Four Lacanian Discourses: or Turning Law Inside-Out. New York: Bircbeck Law Press.

Soysal, Ö. (2006). Günümüz psikopatolojilerine günümüz söylemi bağlamında lacancı bir bakış”, Psikanaliz Yazıları, 12.

Quackelbeen, J. vd. (1994). Hysterical Discourse: Between the Belief in Man and the Cult of Woman.

Bracher, M., Alcorn, M. W., Corthell, R. J., \& Kenney, F. M. (Ed.). Lacanian Theory of Discourse: Subject, Structure and Society içinde (ss. 129-137). New York, London: New York University Press.

Verhaeghe, P. (1995). From impossibility to inability: Lacan's theory on the four discourses. The Letter: Lacanian Perspectives of Lacanian Perspectives on Psychoanalysis, 3, (91-108.)

Wachman, G. (t.b.). The hysteric's discourse. Erişim http://www.lacan.com/hystericdisc.htm 